\title{
Clinical management and reconstruction of isolated orbital floor fractures: The role of computed tomography during preoperative evaluation
}

\author{
İzole orbita tabanı kırıklarına klinik yaklaşım ve \\ ameliyat öncesi değerlendirmede bilgisayarlı tomografinin rolü
}

Nesrin TAN BAŞER, ${ }^{1}$ Refika BULUTOĞLU, ${ }^{2}$ Nihal Uzun ÇELEBİ, ${ }^{1}$ Gürcan ASLAN ${ }^{1}$

\section{BACKGROUND}

A common consent regarding repair indications, timing of repair and choice of reconstruction materials for isolated orbital base fractures does not yet exist.

\section{METHODS}

We retrospectively reviewed our patients (41 male, 13 female) who were operated due to a diagnosis of isolated orbital floor fracture between 2002 and 2010.

\section{RESULTS}

Fifty-four patients diagnosed with isolated orbital base fracture were found; 49 of 54 patients required surgery. The indications for surgery were restricted ocular motility and marked enophthalmos in $20.4 \%$ of the patients, whereas in $79.6 \%$, surgical intervention was decided largely based on the coronal computed tomography images. $36.7 \%$ of the cases were operated earliest, in the first 16 hours, and $10.2 \%$ were operated the latest, in 72-96 hours. Ultra-thin porous polyethylene was used in the orbital base repair. Twelve patients contacted for this study were evaluated. Enophthalmia and exophthalmia were in normal limits in patients, and none of the patients displayed ectropion or scleral show findings or reported any complaints related to scar formation.

\section{CONCLUSION}

When not treated in a timely manner and with appropriate materials, orbital base fractures might result in enophthalmia and diplopia. We believe that a good prognosis of orbital base fractures relies on the right decision for surgical indication, early surgical intervention, and repair with appropriate material.

Key Words: Computed tomography; orbital fractures; orbital implants; X-ray.

\section{AMAÇ}

İzole orbita taban kırıklarının cerrahi endikasyonu, zamanlaması, kullanılacak rekonstrüksiyon materyali hakkında halen görüş birliği yoktur.

\section{GEREÇ VE YÖNTEM}

2002-2010 yılları arasında izole orbita taban kırığ1 tanısı alarak ameliyat edilen hastalar (41 erkek, 13 kadın) geriye dönük olarak değerlendirildi.

\section{BULGULAR}

İzole orbita taban kırığı tanısı alan 54 hastadan, ameliyat edilen 49 hastanın cerrahi endikasyonuna bakıldığında, \%20,4'ünde göz hareketlerinde kısıtlılık ve belirgin enoftalmi, \%79,6'sında koronal planda çekilen bilgisayarlı tomografi görüntülerinin etkili olduğu görüldü. Hastaların \%36,7'si ilk 16 saat içinde \%10,2'si en geç 72-96 saat içinde ameliyat edildi. Orbita taban onarımı için ultra ince poröz polyetilen kullanıldı. Bu çalışma nedeniyle kendilerine ulaşılan 12 hastanın enoftalmi-egzoftalmi açısından normal sınırlarda olduğu, hiçbir hastada ektropiyon ya da skleral show bulgusu olmadığı, hastaların skara bağlı herhangi bir şikayetlerinin olmadığı görüldü.

\section{SONUÇ}

Tedavi edilmediğinde enoftalmi ve çift görme ile sonuçlanabilecek olan orbita taban kırığında, iyi prognoz doğru cerrahi endikasyon, erken cerrahi girişim ve uygun materyal ile onarıma bağlı olduğunu düşünmekteyiz.

Anahtar Sözcükler: Bilgisayarlı tomografi; orbita kırıkları; orbita implantları; X-1şınları.
${ }^{1}$ 2nd Department of Plastic Recostructive and Aesthetic Surgery, Ankara Traning and Research Hospital, Ankara; ${ }^{2}$ Burdur State Hospital, Burdur, Turkey.
${ }^{1}$ Ankara Eğitim ve Araştırma Hastanesi, 2. Plastik Rekonstrüktif ve Estetik Cerrahi Kliniği, Ankara; ${ }^{2}$ Burdur Devlet Hastanesi, Burdur. 
Orbital floor fractures are commonly encountered injuries in facial traumas. Anatomically, the anteromedial one-third of the orbital floor comprises the orbital face of the maxilla, whereas the posteromedial one-third is formed by the palatine bone and the lateral one-third is formed by the zygomatic bone. Generally, fracture occurs over the medial wall and floor of the orbit following trauma. ${ }^{[1]}$ There are various identifications of orbital fractures based on the inclusion or exclusion of the orbital rim. The fractures comprising only the orbital floor are termed as indirect orbital floor fracture, blowout fracture, pure internal

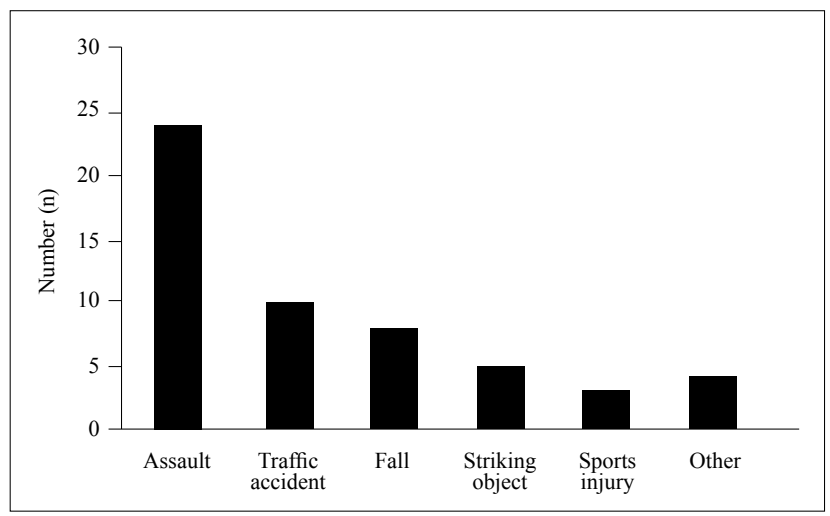

Fig. 1. Injury etiology.

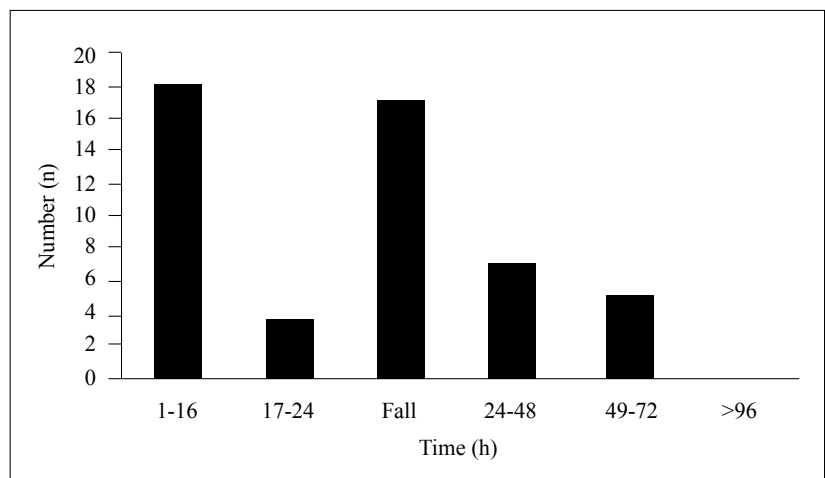

Fig. 2. Distribution of the interval between trauma and surgical repair.

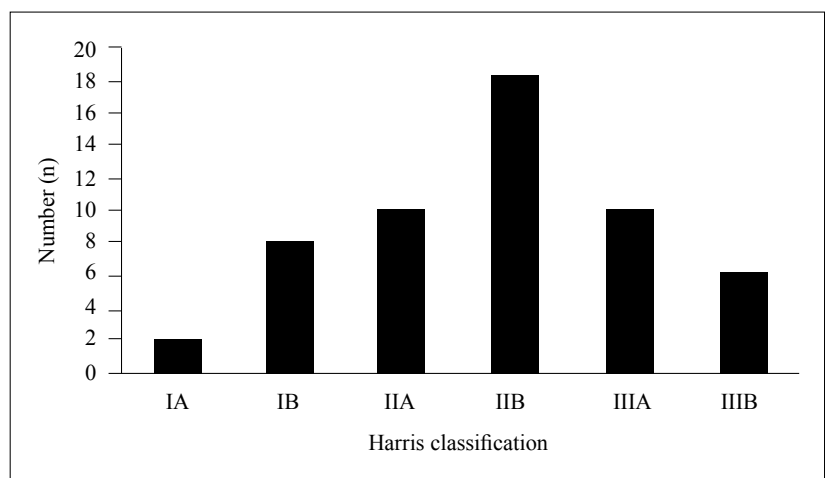

Fig. 3. Distribution of the orbital floor fractures relative to Harris classification.
Table 1. Distribution of the isolated orbital fractures relative to age and gender

\begin{tabular}{lccc}
\hline Age & Woman & Man & Case \\
\hline $0-10$ & 1 & 1 & 2 \\
$11-20$ & 1 & 2 & 3 \\
$21-30$ & 2 & 12 & 14 \\
$31-40$ & 3 & 8 & 11 \\
$41-50$ & 3 & 9 & 12 \\
$51-60$ & 2 & 5 & 7 \\
$>60$ & 1 & 4 & 5 \\
Total cases & 13 & 41 & 54 \\
\hline
\end{tabular}

orbital floor fracture, or isolated orbital floor fracture. ${ }^{[2]}$ Among all maxillofacial fractures, the incidence of orbital fractures is $57.4 \%$ and the incidence of isolated orbital floor fractures is $21.4 \%{ }^{[3]}$

The management of isolated orbital floor fractures has been a contentious issue. Despite many articles published on orbital floor fractures, there is no consensus as yet on many subjects, including the indications for surgery, timing of surgery, surgical method, and choice of reconstruction material. Recent studies and meta-analyses appear to have differing conclusions on the subject. ${ }^{[2,4-6]}$ Because of the varying views on the management of isolated orbital floor fractures, we decided to evaluate the efficacy of our method of clinical management. Therefore, we retrospectively reviewed our patients who had been operated on with the diagnosis of isolated orbital floor fracture between 2002 and 2010.

In this study, we aimed to discuss the efficacy of our management method in cases of isolated orbital floor fractures by reevaluating our indications for surgery, timing of surgery, preferred surgical method, and choice of repair material in light of the recent data collected from our contacted patients and the outcomes of the similar studies in the literature.

\section{MATERIALS AND METHODS}

The study population included patients who presented to our Emergency Room and were diagnosed with isolated orbital floor fracture. The patients with an accompanying maxillofacial fracture were excluded from the study. The following medical data concerning the patients included in our study were reviewed retrospectively: injury etiology, preoperative physical examination findings, computed tomography (CT) results, the interval between the trauma and the surgery, surgical approach, material used in the repair of the orbital floor, and postoperative complications (Figs. 1-3, Tables 1, 2). We evaluated the coronal orbital CT images according to the classification system defined by Harris and colleagues ${ }^{[7]}$ while establishing diagnosis and determining indications for surgery. 
Table 2. Preoperative and early postoperative period findings of the patients

\begin{tabular}{|c|c|c|}
\hline Findings & Time & Case \\
\hline \multicolumn{3}{|l|}{ Diplopia } \\
\hline & Preoperative & 7 \\
\hline & Postoperative & \\
\hline & First 15 days & 9 \\
\hline & 1st month & 4 \\
\hline & 3rd month & 1 \\
\hline & 6th month & - \\
\hline \multicolumn{3}{|l|}{ Hypoesthesia } \\
\hline & Preoperative & 18 \\
\hline & Postoperative & \\
\hline & First 15 days & 18 \\
\hline & 1st month & 10 \\
\hline & 3rd month & 2 \\
\hline & 6th month & - \\
\hline \multicolumn{3}{|l|}{ Enophthalmia } \\
\hline & Preoperative & 4 \\
\hline & Postoperative & \\
\hline & First 15 days & - \\
\hline & 1st month & - \\
\hline & 3rd month & - \\
\hline & 6th month & - \\
\hline \multicolumn{3}{|l|}{ Restricted ocular motility } \\
\hline & Preoperative & 6 \\
\hline & Postoperative & \\
\hline & First 15 days & - \\
\hline & 1st month & - \\
\hline & 3rd month & - \\
\hline & 6th month & - \\
\hline Periorbital ecchymosis & Preoperative & 47 \\
\hline
\end{tabular}

The 2-mm-thick coronal CT images of the study population were assessed based on these criteria, and a graphic showing the fracture types was created (Fig. 3). All the patients were evaluated by an ophthalmolo- gist upon admittance to the Emergency Room. The patients who had indications for surgery were examined for any systemic problem that could complicate the operation prior to the surgery. Intraoperatively, the tissues entrapped between the fractured bone fragments were released, and the defect in the orbital floor was repaired. According to our clinical routine, patients with an orbital floor fracture are operated on and discharged 3 days postoperatively with a prescribed oral antibiotic, called for a follow-up assessment at 5 days for removal of the sutures, and checked once again at 1 week, according to which they are either removed from the follow-up list if everything is normal, or referred to the polyclinic in the event of a problem.

The patients that we succeeded in contacting were invited for an up-to-date follow-up assessment. Those patients were evaluated in terms of ocular motility, diplopia, orbital position of the globe, scarring, ectropion, and complications associated with the implant (Table 3). The orbital position of both normal and traumatized globes was measured by an ophthalmologist using a Hertel exophthalmometer.

\section{RESULTS}

We included 54 patients (41 male, 13 female) with an isolated orbital fracture treated within the specified period. The age range of the patients was 6-65 years, and the mean age was 37.5 years (Table 1). The most common causes of fracture were assault $(n=24,44.4 \%)$, traffic accident $(n=10,18.5 \%)$, fall $(n=8,14.8 \%)$, striking an object $(n=5,9.2 \%)$, sports injury $(n=3,5.5 \%)$, and other causes $(n=4,7.4 \%)$ (Fig. 1). The distribution of the clinical signs and symptoms among the patients was as follows: periorbital edema-ecchymosis (87.0\%), diplopia (12.96\%), enophthalmos (7.4\%), restricted ocular motility $(11.1 \%)$, and hypoesthesia in the infraorbital region (33.3\%) (Table 2).

Table 3. Late postoperative findings of the contacted patients

\begin{tabular}{|c|c|c|c|c|c|c|c|c|c|c|}
\hline \multirow[b]{2}{*}{ No } & \multirow[b]{2}{*}{$\begin{array}{l}\text { Fracture } \\
\text { type }^{*}\end{array}$} & \multirow[b]{2}{*}{$\begin{array}{c}\text { Interval }^{\#} \\
\text { (hours) }\end{array}$} & \multirow[b]{2}{*}{$\begin{array}{l}\text { Causes of } \\
\text { fractures }\end{array}$} & \multicolumn{3}{|c|}{ First PE findings/late-period PE findings } & \multirow[b]{2}{*}{$\begin{array}{c}\text { Incision-rel. } \\
\text { compliant }\end{array}$} & \multirow[b]{2}{*}{ Ectropion } & \multirow[b]{2}{*}{$\begin{array}{l}\text { Implant-rel. } \\
\text { compliant }\end{array}$} & \multirow[b]{2}{*}{$\begin{array}{l}\text { Postop. time } \\
\text { (months) }\end{array}$} \\
\hline & & & & Diplopia & ROM & $\begin{array}{c}\text { Enophthalmos } \\
\text { (mm) }\end{array}$ & & & & \\
\hline 1 & IB & 6 & Striking object & Yes/No & Upgaze/No & $\mathrm{No} /+0.30$ & No & No & No & 72 \\
\hline 2 & IIA & $\begin{array}{c}\text { Not } \\
\text { operated }\end{array}$ & Fall & Yes/No & No/No & $\mathrm{No} /-0.10$ & - & - & - & $\begin{array}{l}\text { P. traumatic } \\
50\end{array}$ \\
\hline 3 & IIA & 28 & Assault & $\mathrm{No} / \mathrm{No}$ & $\mathrm{No} / \mathrm{No}$ & $\mathrm{No} /-0.20$ & Itching & No & No & 8 \\
\hline 4 & IIIA & 9 & Traffic accident & No/No & $\mathrm{No} / \mathrm{No}$ & Yes/-0,50 & No & No & No & 76 \\
\hline 5 & IIIB & 42 & Assault & No/No & $\mathrm{No} / \mathrm{No}$ & Yes/-0.70 & No & No & No & 78 \\
\hline 6 & IIIA & 72 & Fall & $\mathrm{No} / \mathrm{No}$ & $\mathrm{No} / \mathrm{No}$ & $\mathrm{No} /-0.60$ & No & No & No & 65 \\
\hline 7 & IIA & 25 & Assault & Yes/No & $\mathrm{No} / \mathrm{No}$ & $\mathrm{No} /+0,35$ & No & No & No & 27 \\
\hline 8 & IIB & 20 & Fall & Yes/No & Upgaze/No & $\mathrm{No} /-0.40$ & No & No & No & 32 \\
\hline 9 & IIIA & 80 & Assault & $\mathrm{No} / \mathrm{No}$ & $\mathrm{No} / \mathrm{No}$ & $\mathrm{No} /-0.60$ & No & No & No & 53 \\
\hline 10 & IIB & 8 & Assault & Yes/No & $\mathrm{No} / \mathrm{No}$ & $\mathrm{No} /-0.40$ & No & No & No & 58 \\
\hline 11 & IIB & 12 & Assault & Yes/No & $\mathrm{No} / \mathrm{No}$ & $\mathrm{No} /-0.10$ & No & No & No & 36 \\
\hline 12 & IIIA & 27 & Traffic accident & $\mathrm{No} / \mathrm{No}$ & $\mathrm{No} / \mathrm{No}$ & $\mathrm{No} /-0.50$ & No & No & No & 19 \\
\hline
\end{tabular}

*: According to Harris classification ${ }^{[7]}$; PE: Physical examination; ROM: Restricted ocular motility; đ: The orbital position of both normal and traumatized globes was measured by Hertel exophthalmometer. Differences in the measurements between the affected and normal eyes are given. \#: Interval between the trauma and surgery. 


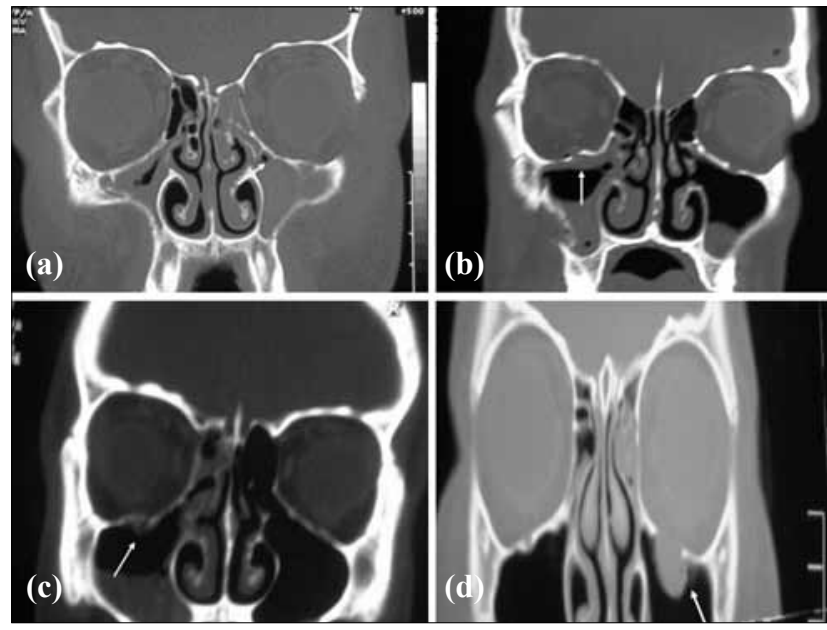

Fig. 4. (a) Type IA fracture with no surgical repair. (b) Type IB fracture. Tissue entrapment is shown by the arrow. (c) Type IIA fracture without surgical indication. Soft tissue is not displaced into the maxillary sinus. (d) Type IIB fracture where there is a marked tissue herniation towards the maxillary sinus.

Forty-nine of 54 patients required surgery. The indications for surgery in our 49 isolated orbital floor fracture cases were restricted ocular motility in 6 patients and marked enophthalmos in 4 patients, whereas in the remaining cases, surgical intervention was decided largely based on the coronal CT images. There was no indication for surgery in 2 patients with a type IA fracture due to presence of a fissure fracture and in 3 patients with type IIA fracture due to absence of soft tissue herniation towards the maxillary sinus, and no problem was experienced in the follow-up of those patients (Fig. 4a, 4c). In terms of the interval between the trauma and the surgery, $36.7 \%$ of the cases were operated within the first 16 hours and $10.2 \%$ at the latest, within 72-96 hours (Fig. 2). Subciliary incision was the preferred surgical approach in all the operated cases. In 6 of the 8 patients with a trapdoor fracture (type IB), bone was reduced to its former place after releasing the soft tissues (Fig. 4b). In 43 patients, ultra-thin porous polyethylene $(0.85 \mathrm{~mm} \times 38 \mathrm{~mm}$ x $50 \mathrm{~mm}$ Medpor $^{\circledR}$, Porex Surgical, Inc., College Park, GA) implant was used for orbital floor reconstruction. Depending on the size of the orbital floor defect, the implant material was cut in a circle and placed accordingly; it was not fixated except in 6 patients with a large defect (Fig. 5). Prior to finalizing the operation, all patients were subjected to forced duction test, and the movement capability of the eye was checked in all directions.

Regarding the early postoperative follow-ups, the follow-up period was observed to range between 4-12 weeks. None of the patients demonstrated restricted ocular motility or enophthalmos except 1 in 9 diplopia patients who experienced diplopia until postopera-

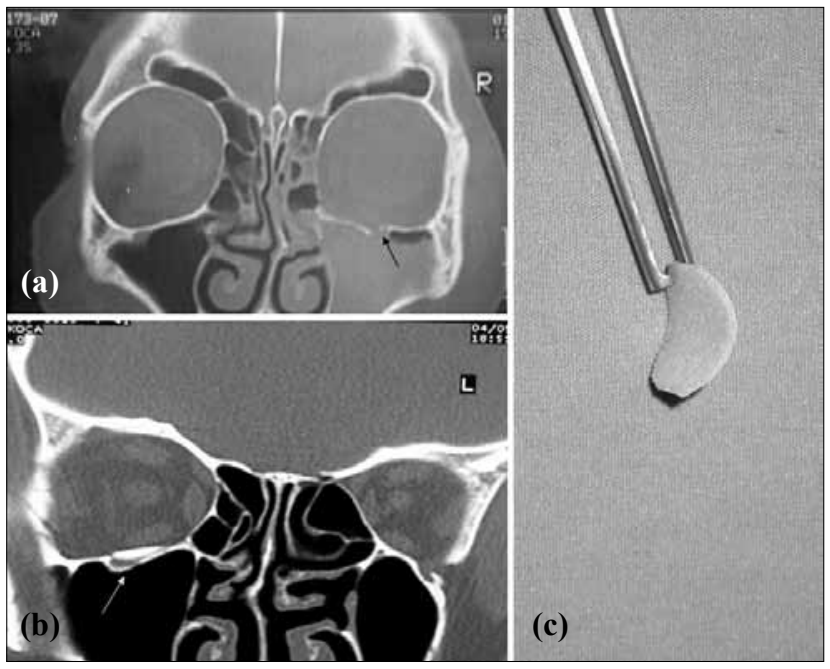

Fig. 5. (a) Type IIB fracture over the right orbital floor. (b) Round porous polyethylene implant. (c) Appearance of the implant material and orbital floor at postoperative 2 months [The right side appears to vary due to printing of the CT images in the opposite direction].

tive 12 weeks. Hypoesthesia was present in some patients but it resolved by the 6th month (Table 2). Three (6.12\%) patients developed incision-related ectropion, and in 2 patients, ectropion was resolved by massage within 4-6 weeks, whereas 1 patient required surgery. During the postoperative first week, 1 patient developed infection following surgery. The infection was controlled with broad spectrum intravenous (i.v.) antibiotic therapy. The infection regressed and the patient did not require removal of the implant. This patient developed ectropion resulting from the contraction over the suture line. Since it was a severe ectropion case, the patient was operated on and a full-thickness skin graft was placed over this region. None of the patients showed a complication involving displacement or extrusion of the porous polyethylene implant.

We were able to contact only 18 of the 54 patients chosen for the assessment of late sequelae. However, only 12 of those patients agreed to participate in the late postoperative assessment. The findings involving the late postoperative assessment of those 12 patients are shown in Table 3 . The postoperative time for the patients included in the assessment ranged between 8 months - 6.5 years. Late assessment of 2 patients, who had marked enophthalmos prior to the operation, revealed no difference between the affected and normal eyes in the measurements performed using Hertel exophthalmometer. Late-period assessment of the patients who had diplopia or restricted ocular motility prior to the surgery revealed that those pathologies were resolved. None of the patients exhibited ectropion. No patient had a complaint about the subciliary incision. The implant placed over the orbital floor showed no extrusion. 


\section{DISCUSSION}

According to the current literature, isolated orbital floor fractures are recognized as an indication for emergency surgery. Burnstine ${ }^{[4]}$ conducted a metaanalysis in 2002 and listed the indications for emergency surgery as follows: entrapped muscle or soft tissue on CT images with concurrent diplopia, accompanying oculocardiac reflex (bradycardia, cardiac block, nausea, vomiting, or syncope), mild presence or absence of edema, ecchymosis, markedly limited extraocular motility, and white-eyed blowout fractures that indicate orbital floor fractures shown by $\mathrm{CT}$ along with muscle or perimuscular soft tissue entrapment in patients under 18 years of age. The meta-analysis of Gonzales and colleagues ${ }^{[2]}$ on isolated orbital floor fractures listed the same indications for emergency (within 24-48 hours) repair. There is no controversial or contentious point in the literature concerning the surgical indication or timing of surgery under the above-mentioned conditions. The main ambiguity is experienced while determining surgery and the timing of the surgery in conditions other than the those listed above. Dal Canto et al. ${ }^{[8]}$ compared the patients $(n=58)$ who had been operated on early (1-14 days) and late (15-29 days), and found no statistically significant difference between the postoperative diplopia and enophthalmos rates, while observing no statistically significant difference between the two groups with regard to strabismus surgery or use of special glasses. Thus, they reported effective outcomes in surgeries performed in 15-29 days and noted that waiting for the diplopia to resolve could spare the patients from unnecessary interventions.

Simon et al. ${ }^{[5]}$ published a study in 2009 and noted that this waiting period should be even longer. In their study including 50 patients (36 cases were isolated orbital floor fractures) in which they compared early repairs (performed within the first 2 weeks) and late repairs (performed within 1 month - 3.5 years), they found no difference with regard to postoperative surgical outcome. In light of their findings, except emergency cases, they recommended early repair only in the presence of symptomatic diplopia, positive forced duction test and large orbital floor fractures that would result in enophthalmos, and they noted that in cases other than those, surgery should be delayed for 6-9 months until the resolution of the diplopia. However, when the article is analyzed, it can be seen that there is no difference between the two groups in terms of visual acuity and ocular motility, whereas it can be observed that the enophthalmos rate was higher in the late surgery group than in the early surgery group. Contrary to the studies recommending waiting for a certain period of time, there are surgeons who advocate early surgery because of the more flexible nature of the fracture line and the easy-to-release character of the herniating tissue as well as availability of a less traumatic intervention, with low diplopia and enophthalmos incidences during the early period. ${ }^{[9-14]}$ In our case series, except for the 6 patients showing an indication for emergency surgery, patients exhibiting an indication for surgery were operated on within a time range of 6 - 92 hours (Fig. 2).

We believe that timing of the reconstruction bears great importance in reestablishing the globe support that is lost in orbital floor fractures and in retaining the orbital volume in order to prevent possible functional and cosmetic problems. The fact that none of the patients showed enophthalmos values requiring surgery supports our point of view (Table 3 ). In our clinic, we do not apply forced duction test as a diagnostic preoperative assessment. This test might be embarrassing when applied on awake patients. Moreover, according to Hollier and Thornton, ${ }^{[15]}$ it may not be successful in acute cases. It is claimed that this test does not indicate whether restricted eye motility in the early period arises from a mechanic muscle entrapment or edema and hemorrhage. ${ }^{[16]}$

Generally, early enophthalmos occurs due to detachment of the periosteum of the orbital floor, leading to herniation of the content into the maxillary sinus or elevated orbital volume associated with the posterior displacement of the orbital floor. Early enophthalmos can be masked by traumatic hemorrhage and edema. ${ }^{[17]}$ For these reasons, we believe that preoperative measurement of enophthalmos would not provide accurate data in those patients. Therefore, clinically, the degree of enophthalmos is not measured preoperatively.

Limited anteroposterior healing of the eye due to extraocular muscle contraction or fibrosis of the orbital tissue is cited as responsible for late enophthalmos. ${ }^{[15,17]}$ Correction of late enophthalmos is more difficult than prevention of enophthalmos with early surgery. As reported in many studies, dissection becomes more difficult due to progressing fibrosis. ${ }^{[10,14,18]}$ Unlike Simon et al., Dulley and Fells ${ }^{[19]}$ found the postoperative enophthalmos incidence as $72 \%$, and reported that $40 \%$ of those required additional surgery.

Many studies have reported inadequate assessment of restricted ocular motility, diplopia and enophthalmos during the early period because of edema. ${ }^{[20,21]}$ This swelling may also limit the extraocular muscle movements, which would appear like tissue entrapment within the orbital floor defect. Therefore, we believe that 2-mm-thick coronal CT imaging bears great importance in the diagnosis and decision for surgery. Coronal CT imaging is recognized as the best modality in determination of the location and size of the orbital fractures, globe prolapse, accompanying fractures, and likely optical nerve damages as well as being the 
most helpful method in preoperative assessment. ${ }^{[6,10,20]}$

There are studies published on calculation of the orbital volume on 3D orbital tomography images or concerning measurement of the related areas on 2D coronal images. ${ }^{[18,20,22]}$ The downside of those quantitative CT analyses is noted to be the influence of soft tissue changes such as edema, hemorrhage and emphysema on the measurement results. ${ }^{[23]}$ Moreover, these measurements require additional software and technical equipment. Harris et al. ${ }^{[7]}$ categorized the isolated orbital floor fractures with the help of CT images based on the relationship between fractured bone fragments and the soft tissues as 3 main types and 6 subtypes. This classification is outlined below:

Type I. Trap-door fractures in which bone fragments realign.

Type IA. No orbital soft tissue is visible within the maxillary sinus (Fig. 4a).

Type IB. Orbital soft tissue is visible within the maxillary sinus (Fig. 4b).

Type II. Bone fragments are distracted and soft tissue is displaced towards the maxillary sinus through spaces between those fragments.

Type IIA. There is no herniation of soft tissue or the displacement of the soft tissue is less than the distracted bone fragment.

Type IIB. The herniation of soft tissue is greater than the distracted bone fragment.

Type III. Displaced bone fragments surround displaced soft tissue.

Type IIIA. Soft tissue and bone are moderately displaced towards the maxillary sinus (Fig. 6a).

Type IIIB. Soft tissue and bone are markedly displaced towards the maxillary sinus (Fig. 6b).

We believe that evaluation of patients based on the $\mathrm{CT}$ images and Harris classification is adequate for determining whether surgery is indicated..$^{[7,10,24]}$

In our case series, enophthalmos was detected by physical examination only in 4 patients in the early period following injury. While 1 patient had Type IIIA fracture, the remaining 3 had Type IIIB fracture. The other 13 cases diagnosed as Type IIIA and Type IIIB fractures based on the CT images demonstrated no enophthalmos or restricted ocular motility during the physical examination. In one study, the incidence of enophthalmos after weeks or months of injury was noted as $8-54 \% .{ }^{[25]}$ Based on those CT images, the patients were subjected to early surgery. In our study, the mean operative time was 34 hours for 49 isolated orbital floor fracture cases. We think that performing early surgery reduced the surgical trauma by avoiding fat atrophy, fibrosis and contraction, and thus prevented future occurrence of diplopia and enophthalmos in our cases. Successful orbital floor reconstruction depends on meticulous preoperative planning, careful dissection and the accurate selection of reconstruction material. The ideal implant should be of an inert and easily malleable character; should allow tissue in-growth and form no fibrous capsule; and should have low infection, inflammation, migration, and removal rates..$^{[5,18]}$

Various materials are used in reconstruction of the orbital floor, such as autogenic grafts (bone, cartilage, fascia, etc. $),{ }^{[26-31]}$ allogenic grafts, ${ }^{[32,33]}$ and alloplastic materials (silicone, polytetrafluoroethylene, hydroxylapatite, porous polyethylene, titanium, and Vitallium mesh). ${ }^{[34-41]}$ There are studies outlining their advantages, disadvantages and success rates. Cadaver-based allogenic bone grafts are not preferred due to risk of viral infection transmission, resorption rate and their costly nature. ${ }^{[31]}$ Among some of the advantages of alloplastic materials are the absence of donor-site morbidity, ready availability, and wide range of options, whereas foreign body reaction and infection are noted among their disadvantages. ${ }^{[39]}$ The upsides of autogenous grafts (calvaria, nasal septal bone, cartilage, etc.)
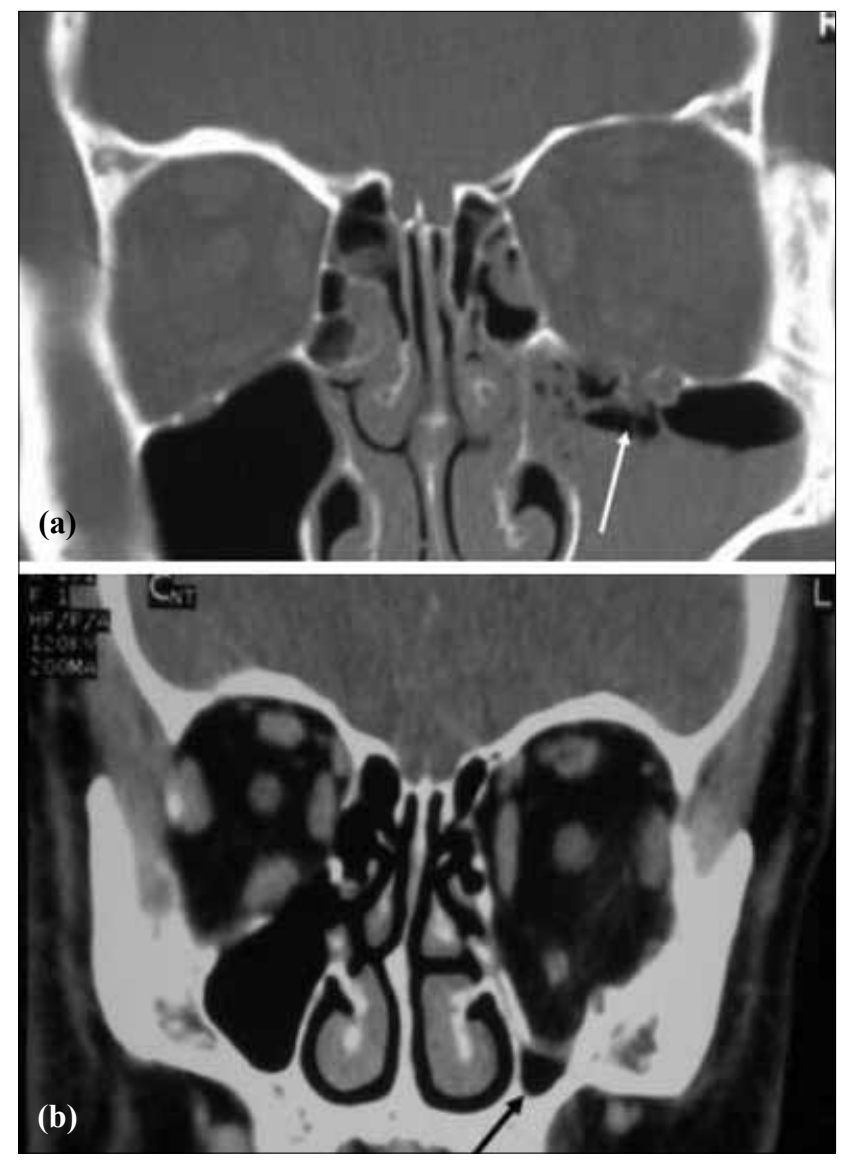

Fig. 6. (a) Type IIIA fracture with displacement of bone and soft tissues into the maxillary sinus. (b) Type IIIB fracture with marked displacement of the osseous and soft tissues into the maxillary sinus. 
are rapid vascularization, bone formation and low resorption, whereas their downsides are donor-site morbidity, hardly malleable nature and prolonged operative time.${ }^{[39,42]}$ Maybe the most important disadvantage of autogenous grafts is the unpredictable resorption rate and likelihood of late enophthalmos associated with reduced graft volume. ${ }^{[42]}$

There is still no consensus among the surgeons in the selection of the reconstruction material between autogenous and alloplastic grafts. Ilankovan ${ }^{[43]}$ studied a case series of 222 patients and reported successful esthetic and functional outcomes by using calvarial bone graft. Shetty et al. ${ }^{[44]}$ compared the autogenous graft [calvarial bone graft] and alloplastic material (Prolene and titanium) in a case series including 10 patients, and found both materials appropriate for reconstruction, but noted the need for further studies with larger study populations. Prowse et al. ${ }^{[36]}$ conducted a study on a case series of 81 patients by employing silicone implant, titanium mesh, Lactosorb, Resorb $\mathrm{X}$, and autogenous bone and cartilage, and reported that contrary to the literature, silicone implants could be used because of low infection and excursion rates as well as high patient satisfaction. Morrison et al. ${ }^{[45]}$ found the rate of removal of implant due to infection or excursion as $12 \%$. Currently, the most commonly used alloplastic implant materials are titanium and porous polyethylene. Porous polyethylene is composed of high-density micropores connected to each other, which allow fibrovascular tissues to advance into the implant. This structure provides a certain rigidity to the polyethylene and allows it to automatically fixate itself to the adjacent tissues. There are many studies showing the superiority of porous polyethylene over other graft materials. ${ }^{[34,35,41]} \mathrm{Ng}$ et al. ${ }^{[13]}$ performed a study on 30 orbital floor fracture cases treated by porous polyethylene, and none of the patients exhibited a need for removal of the implant within a follow-up period of 9 months. They described the porous polyethylene layer as a strong and easily malleable material preventing donor-site morbidity. Moreover, orbital volume was found to be increased in orbital reconstruction with porous polyethylene; however, the difference was not statistically significant compared with those of the other orbits. One of the largest studies in the literature on complications of porous polyethylene belongs to Lee and colleagues. ${ }^{[46]}$ They reconstructed 170 cases of orbital floor fracture by porous polyethylene and reported the complication rate as $6.4 \%$. They noted a low complication rate along with perfect functional and cosmetic outcomes in their reconstructions performed with porous polyethylene.

Our experiences suggest that porous polyethylene enables rapid repair of the floor fracture, establishing stability in a short time owing to the fast ingrowth of the fibrovascular tissue within the implant. No implant fixation was applied except in 6 patients with markedly large defects, and no problem was encountered. In our study, only 1 patient developed infection, which regressed with i.v. antibiotic therapy. No sign of implant-related early extrusion, enophthalmos or exophthalmos related to elevated volume was determined. When we analyzed the measurements obtained by Hertel exophthalmometer while reviewing the late follow-up assessments of the 12 patients, development of late enophthalmos associated with reduced volume appears to be impossible with this material because it does not display resorption, which is known to be the most important downside of autogenous materials. In some patients, orbital volume was elevated; however, when the orbital position of the globe was compared between the affected and contralateral orbits, this increase was observed to be insignificant and unrelated to exophthalmos (Table 3).

In the literature, surgical complications of orbital floor fractures are listed as optic nerve injury, retrobulbar hemorrhage and edema-related loss of vision (0.24-3.1\%), infection or displacement of the implant material, postoperative mydriasis, epiphora, and eyelid malposition. ${ }^{[6]}$ Ellis et al. ${ }^{[47]}$ advocates that when correct implant material is used in the orbital reconstruction, the complications are not associated with the implant material.

In our clinic, we used 0.85 -mm-thick porous polyethylene for all the orbital floor defects in patients treated with implants. In 2 of 6 patients with a markedly large defect, the implant material was fixated to the orbital floor by microscrews, while in other patients, the implant was fixated to the periosteum by Prolene sutures. The remaining patients received no fixation. None of the patients complained of implant displacement or migration. We preferred ultra-thin porous polyethylene implant due to its malleable, thin, inert, and infection-resistant nature, requiring no fixation or additional surgical procedures.

Another focus of ongoing discussion concerning orbital floor fractures is the type of incision. In recent studies, the transconjunctival approach is more commonly preferred, whereas subciliary incision is mentioned with high complication rates. The transconjunctival approach is known to be more successful than the subciliary approach with regard to ectropion. ${ }^{[5,48,49]}$ However, one should bear in mind that the transconjunctival approach may require lateral canthotomy for better vision, and this procedure carries the risk of entropion and canthal displacement. In $3(6.1 \%)$ of 49 patients who received subciliary incision for insertion of the implant, ectropion was encountered. While in 2 of them, ectropion was resolved with massage at 3 months, 1 patient required surgery. 
The mean follow-up period of the 12 patients that we succeeded in contacting ranged between 8 months - 6.5 years. These patients were evaluated in terms of enophthalmos, exophthalmos, diplopia, restricted ocular motility, ectropion, and scarring. In light of our measurements, the patients were observed to be within normal range with regard to enophthalmos-exophthalmos, while no sign of ectropion or scleral show was observed. Moreover, the patients had no complaint associated with scarring.

In conclusion, the diagnosis and treatment of orbital floor fractures bear great importance because they may result in enophthalmos and diplopia if not treated in a timely manner and with the appropriate construction material. This study showed that good prognosis in orbital floor fractures depends on accurate determination of the indications of surgery, early surgical intervention and selection of proper reconstruction material.

The evaluation of enophthalmos, diplopia and ocular motility is not easy in the early period due to the presence of edema. Therefore, assessment of the coronal CT images and experience level of the surgeon play as significant a role as the clinical symptoms of the patient in deciding on surgery. In our opinion, detection of bone fragments within the maxillary sinus or herniation of the orbital content into the maxillary sinus both constitute an indication for surgery.

This retrospective study reflects our eight-year experience on isolated orbital fractures and shows that early surgery for insertion of porous polyethylene implants by the subciliary approach can be performed with low complication rates and high patient satisfaction. We believe that early surgery prevents late enophthalmos and diplopia complications.

\section{REFERENCES}

1. Bandyopadhyay LCTK, Sapru BBL. Management of an isolated orbital blow-out fracture. MJAFI 2004;60:392-4.

2. Gonzalez MO, Durairaj VD. Indirect orbital floor fractures: a meta-analysis. Middle East Afr J Ophthalmol 2010;17:13841.

3. Scherer M, Sullivan WG, Smith DJ Jr, Phillips LG, Robson MC. An analysis of 1,423 facial fractures in 788 patients at an urban trauma center. J Trauma 1989;29:388-90.

4. Burnstine MA. Clinical recommendations for repair of isolated orbital floor fractures: an evidence-based analysis. Ophthalmology 2002;109:1207-10.

5. Simon GJ, Syed HM, McCann JD, Goldberg RA. Early versus late repair of orbital blowout fractures. Ophthalmic Surg Lasers Imaging 2009;40:141-8.

6. Gosau M, Schöneich M, Draenert FG, Ettl T, Driemel O, Reichert TE. Retrospective analysis of orbital floor fractures-complications, outcome, and review of literature. Clin Oral Investig 2011;15:305-13. doi: 10.1007/s00784-010-0385-y.

7. Harris GJ, Garcia GH, Logani SC, Murphy ML, Sheth BP, Seth AK. Orbital blow-out fractures: correlation of preopera- tive computed tomography and postoperative ocular motility. Trans Am Ophthalmol Soc 1998;96:329-53.

8. Dal Canto AJ, Linberg JV. Comparison of orbital fracture repair performed within 14 days versus 15 to 29 days after trauma. Ophthal Plast Reconstr Surg 2008;24:437-43.

9. Dutton JJ. Management of blow-out fractures of the orbital floor. Surv Ophthalmol 1991;35:279-80.

10. Harris GJ. Orbital blow-out fractures: surgical timing and technique. Eye (Lond) 2006;20:1207-12.

11. Nam SB, Bae YC, Moon JS, Kang YS. Analysis of the postoperative outcome in 405 cases of orbital fracture using 2 synthetic orbital implants. Ann Plast Surg 2006;56:263-7.

12. Bansagi ZC, Meyer DR. Internal orbital fractures in the pediatric age group: characterization and management. Ophthalmology 2000;107:829-36.

13. Ng SG, Madill SA, Inkster CF, Maloof AJ, Leatherbarrow B. Medpor porous polyethylene implants in orbital blowout fracture repair. Eye (Lond) 2001;15:578-82.

14. Hoşal BM, Beatty RL. Diplopia and enophthalmos after surgical repair of blowout fracture. Orbit 2002;21:27-33.

15. Hollier L, Thornton J. Facial fractures I: Upper two thirds. Selected Read Plast Surg 2002;9:1-34.

16. Ansons AM, Davis H. Mechanical disordere of ocular motility. In: Ansons AM, Davis H, editors. Diagnosis and management of ocular motility disorders. 3rd ed. Malden: Blackwell Science Ltd; 2001. p. 420-74.

17. Ball JB Jr. Direct oblique sagittal CT of orbital wall fractures. AJR Am J Roentgenol 1987;148:601-8.

18. Ye J, Kook KH, Lee SY. Evaluation of computer-based volume measurement and porous polyethylene channel implants in reconstruction of large orbital wall fractures. Invest Ophthalmol Vis Sci 2006;47:509-13.

19. Dulley B, Fells P. Long-term follow-up of orbital blow-out fractures with and without surgery. Mod Probl Ophthalmol 1975;14:467-70.

20. Ploder O, Oeckher M, Klug C, Voracek M, Wagner A, Burggasser $\mathrm{G}$, et al. Follow-up study of treatment of orbital floor fractures: relation of clinical data and software-based CTanalysis. Int J Oral Maxillofac Surg 2003;32:257-62.

21. Whitehouse RW, Batterbury M, Jackson A, Noble JL. Prediction of enophthalmos by computed tomography after 'blow out' orbital fracture. Br J Ophthalmol 1994;78:618-20.

22. Charteris DG, Chan CH, Whitehouse RW, Noble JL. Orbital volume measurement in the management of pure blowout fractures of the orbital floor. Br J Ophthalmol 1993;77:100-2.

23. Manson PN, Iliff N. Management of blow-out fractures of the orbital floor. II. Early repair for selected injuries. Surv Ophthalmol 1991;35:280-92.

24. Harris GJ, Garcia GH, Logani SC, Murphy ML. Correlation of preoperative computed tomography and postoperative ocular motility in orbital blowout fractures. Ophthal Plast Reconstr Surg 2000;16:179-87.

25. Stasior OG, Roen JL. Traumatic enophthalmos. Ophthalmology 1982;89:1267-73.

26. Girdler NM, Hosseini M. Orbital floor reconstruction with autogenous bone harvested from the mandibular lingual cortex. Br J Oral Maxillofac Surg 1992;30:36-8.

27. Harsha BC, Turvey TA, Powers SK. Use of autogenous cranial bone grafts in maxillofacial surgery: a preliminary report. J Oral Maxillofac Surg 1986;44:11-5.

28. Krishnan V, Johnson JV. Orbital floor reconstruction with autogenous mandibular symphyseal bone grafts. J Oral Maxillofac Surg 1997;55:327-32. 
29. Johnson PE, Raftopoulos I. In situ splitting of a rib graft for reconstruction of the orbital floor. Plast Reconstr Surg 1999; 103:1709-11.

30. Cavusoglu T, Vargel I, Yazici I, Cavusoglu M, Vural AC. Reconstruction of orbital floor fractures using autologous nasal septal bone graft. Ann Plast Surg 2010;64:41-6.

31. Baran CN, Ulusoy MG, Sungur N, Koçer U, Şensöz Ö. Reconstruction of orbital floor defects with auricular conchal cartilage grafts. Turkiye Klinikleri J Med Sci 2003;23:442-9.

32. Yavuzer R, Tuncer S, Başterzi Y, Işik I, Sari A, Latifoğlu O. Reconstruction of orbital floor fracture using solvent-preserved bone graft. Plast Reconstr Surg 2004;113:34-44.

33. Celiköz B, Duman H, Selmanpakoğlu N. Reconstruction of the orbital floor with lyophilized tensor fascia lata. J Oral Maxillofac Surg 1997;55:240-4.

34. Yilmaz M, Vayvada H, Aydin E, Menderes A, Atabey A. Repair of fractures of the orbital floor with porous polyethylene implants. Br J Oral Maxillofac Surg 2007;45:640-4.

35. Ozturk S, Sengezer M, Isik S, Turegun M, Deveci M, Cil Y. Long-term outcomes of ultra-thin porous polyethylene implants used for reconstruction of orbital floor defects. J Craniofac Surg 2005;16:973-7.

36. Prowse SJ, Hold PM, Gilmour RF, Pratap U, Mah E, Kimble FW. Orbital floor reconstruction: a case for silicone. A 12 year experience. J Plast Reconstr Aesthet Surg 2010;63:1105-9.

37. Ng JD, Huynh TH, Burgett R. Complications of bioabsorbable orbital implants and fixation plates. Ophthal Plast Reconstr Surg 2004;20:85-6.

38. Tuncer S, Yavuzer R, Kandal S, Demir YH, Ozmen S, Latifoglu O, et al. Reconstruction of traumatic orbital floor fractures with resorbable mesh plate. J Craniofac Surg 2007;18:598605.

39. Chowdhury K, Krause GE. Selection of materials for orbital floor reconstruction. Arch Otolaryngol Head Neck Surg
1998;124:1398-401.

40. Dietz A, Ziegler CM, Dacho A, Althof F, Conradt C, Kolling $\mathrm{G}$, et al. Effectiveness of a new perforated $0.15 \mathrm{~mm}$ poly-pdioxanon-foil versus titanium-dynamic mesh in reconstruction of the orbital floor. J Craniomaxillofac Surg 2001;29:828.

41. Aygıt CA, Demiralay A, Bayçın N. Reconstructıon of orbital blow-out fractures bone defects with porous polyethylene implants. Ulus Travma Acil Cerrahi Derg 1999;5:175-9.

42. Goiato MC, Demathé A, Suzuki T, dos Santos DM, Dekon SF. Management of orbital reconstruction. J Craniofac Surg 2010;21:1834-6.

43. Ilankovan V, Jackson IT. Experience in the use of calvarial bone grafts in orbital reconstruction. Br J Oral Maxillofac Surg 1992;30:92-6.

44. Shetty P, Kumar SG, Baliga M, Uppal N. Options in orbital flor reconstruction in blowout fractures: a review of ten cases. J Maxillofac Oral Surg 2009;8:137-40.

45. Morrison AD, Sanderson RC, Moos KF. The use of silastic as an orbital implant for reconstruction of orbital wall defects: review of 311 cases treated over 20 years. J Oral Maxillofac Surg 1995;53:412-7.

46. Lee S, Maronian N, Whipple ME, Most SP, Whipple ME, McCulloch TM, et al. Porous high-density polietilen for orbital reconstruction. Arch Otolaryngol Head Neck Surg 2005;131:466-50.

47. Ellis E 3rd, Tan Y. Assessment of internal orbital reconstructions for pure blowout fractures: cranial bone grafts versus titanium mesh. J Oral Maxillofac Surg 2003;61:442-53.

48. Tadj A, Kimble FW. Fractured zygomas. ANZ J Surg 2003;73:49-54.

49. Rohrich RJ, Janis JE, Adams WP Jr. Subciliary versus subtarsal approaches to orbitozygomatic fractures. Plast Reconstr Surg 2003;111:1708-14. 